\title{
MULTIPLE CRITERIA ASSESSMENT OF HIGH-RISE TIMBER BUILDINGS
}

\author{
Laura TUPE்NAITE $\dot{1}^{*}$, Viktorija ŽILE்NAITE ${ }^{1}$, Loreta KANAPECKIENE ${ }^{1}$, \\ Seyed Masoud SAJJADIAN ${ }^{2}$, Tomas GEČYS ${ }^{3,4}$, \\ Lina SAKALAUSKIENE ${ }^{5}$, Jurga NAIMAVIČIENE ${ }^{1}$ \\ ${ }^{1}$ Department of Construction Management and Real Estate, Faculty of Civil Engineering, \\ Vilnius Gediminas Technical University, Vilnius, Lithuania \\ ${ }^{2}$ Southampton Solent University, Southampton, United Kingdom \\ ${ }^{3}$ Department of Steel and Composite Structures, Faculty of Civil Engineering, \\ Vilnius Gediminas Technical University, Vilnius, Lithuania \\ ${ }^{4} J S C$ "Idea Statika", Vilnius, Lithuania \\ ${ }^{5}$ Faculty of Civil Engineering, Vilnius College of Technologies and Design, Vilnius, Lithuania
}

Received 19 December 2019; accepted 09 January 2020

\begin{abstract}
Although the majority of high-rise buildings are constructed from concrete and steel, there is a growing interest in the new generation of multi-storey timber buildings around the world and several ecologically sustainable structural systems have already been proposed. This research aims to review and compare the highest contemporary timber buildings in terms of economic and environmental efficiency. For this purpose, the Simple Additive Weighting (SAW) method is used. Five high-rise timber buildings are assessed according to the developed system of economic and environmental criteria. According to the multiple criteria assessment results, Mjøsa Tower, currently the tallest timber building in the world, located in Brumunddal, Norway, is ranked in the first place. This study also reveals that high-rise timber buildings are environmental friendly and high economic efficiency can be achieved by using lightweight modern engineered timber products, moreover, prefabrication of elements reduces duration and cost of the project.
\end{abstract}

Keywords: high-rise timber buildings, engineered timber products, structural systems, economic and environmental performance, multiple criteria assessment, SAW.

\section{Introduction}

Contemporary technological advancements make it possible to design and construct complex buildings. Globally, reinforced concrete, metal and glass have been commonly used in the construction of high-rise buildings for many reasons. At the end of the 19th century, cities were subject to frequent fires, which led to the introduction of fire protection measures, including legal measures prohibiting the use of timber structures for the construction of high-rise buildings. As a result, reinforced concrete buildings took the largest share of the newly built multi-storey buildings' market (Mahapatra, Gustavsson, \& Hemström, 2012). In late 1980, the European Commission confirmed that timber, concrete and steel structures that meet the functional requirements described in national building regulations may be used for the construction of high-rise buildings. However, architects, designers and developers were still increasingly choosing steel and reinforced concrete structures, and timber use in multi-storey buildings was still rare.

Doubts about the quality and characteristics of timber structures in many countries are caused by various perceptions. It is commonly believed that timber structures change their dimensions over time, they are not stable and durable, not resistant to moisture and pests and extremely flammable. These public perceptions have been shaped by poor construction practices, where improperly prepared or used timber materials lost their characteristics and durability.

Despite the aforementioned obstacles, the interest in the new generation of multi-storey timber buildings has consequently increased around the world. Timber building materials proved to cause considerably lower climate

${ }^{*}$ Corresponding author. E-mail: laura.tupenaite@vgtu.lt 
change impact compared to materials like steel and concrete (Skullestad, Bohne, \& Lohne, 2016). Moreover, modern engineered timber products provided opportunities to build high. In the last decade, 6 storeys timber buildings and higher have been constructed, and engineers have begun to look at the possibility of building much taller with timber (Ramage et al., 2017), demonstrating successful applications of new wood and mass timber technologies.

For a long time, Murray Grove, a 9-storey housing block in Hackney, built in 2009, was the highest timber building in the world. At present $85.4 \mathrm{~m}$-tall 18-storey Mjøsa Tower is the tallest timber building globally. Higher timber buildings are designed and expected in the future. Here the question arises whether higher timber buildings are efficient in terms of economic and environmental indicators? Therefore, the aim of the present research is to review and compare the highest contemporary timber buildings from an economic and environmental perspective.

The paper is organized as follows. Section 1 contains a literature review on high-rise timber buildings, modern engineered timber products used in construction and the benefits of building in timber. Section 2 provides a methodology for comparison and the assessment of high-rise timber buildings based on the Simple Additive Weighting (SAW) multiple criteria assessment method. In Section 3 multiple criteria assessment of the selected highest timber buildings is performed: buildings under comparison are described, economic and environmental assessment criteria and their significances are determined, multiple criteria assessment to find the most efficient building in terms of the selected criteria is performed. The last section concludes the paper, provides limitations and insights for the future research.

\section{Literature review}

A 'tall building' is usually defined as a multi-storey structure with elevators for occupants to reach their destinations. The most prominent tall buildings are called 'highrise buildings' in most countries. In absolute numbers, these buildings are at least 23-30 meters high and have at least 5 stories (depending on the slab-to-slab distance between floors) (Craighead, 2003).

High-rise buildings have traditionally been constructed using concrete, steel, or a combination of the two. However, several timber skyscrapers have already been designed and built in the world, with the tallest the Mjøsa Tower, an 80-meter-tall-plus building in Brumunddal, Norway. A number of high profile architects and engineers are trying to recast wood as a material fit for the 21 st Century. Currently, most popular engineered timber products used in high-rise timber buildings are produced based on laminating and gluing:

- Glued laminated timber (glulam);

- Cross laminated timber (CLT);

- Laminated veneer lumber (LVL).

Glued laminated timber, also called glulam, is the oldest glued structural product (over 100 years). It is generally composed of lumber layers $(2 \times 3$ to $2 \times 12)$, planed and pre-finger-jointed, and then bonded together with moisture- resistant structural adhesives longitudinally (Avellan, 2018; Quebec Wood Export Bureau [QWEB], 2015) (Figure 1). Large straight or curved sections can be produced, providing more stability than heavy lumber. Glulam can be used for columns, beams, or arches, in lengths mainly limited because of transport.

Cross laminated timber (CLT) was developed around 15 years ago in Central Europe. CLT is a solid engineered wood panel, made up of cross angled timber boards which are glued (Avellan, 2018) (Figure 1). It distinguishes from other products by superior thermal and acoustical performance, high fire resistance and structural strength (QWEB, 2015). CLT elements in a combination with a concrete core and structural outriggers can be used to build very tall buildings, for instance, CLT has already been shown to be very efficient in multi-storey buildings up to 10 storeys (Van De Kuilen, Ceccotti, Xia, \& He, 2011).

Laminated veneer lumber (LVL) is an engineered wood product made up with thin dried wood and bonded with adhesive (Avellan, 2018). It can be used for beams, walls, other structures and forming of edges. LVL is a type of structural composite lumber. Due to its composite nature, it is much less likely than conventional lumber to warp, twist, bow, or shrink, and has higher allowable stress compared to glulam (QWEB, 2015). A sound prediction of the non-linear behaviour of the LVL beams before failure is also observed (Gilbert, Bailleres, Zhang, \& McGavin, 2017).

Recent interest in high-rise timber buildings is related to sustainability and other substantial benefits of wood. Wood is the only renewable construction material that requires very little energy for its processing (QWEB,
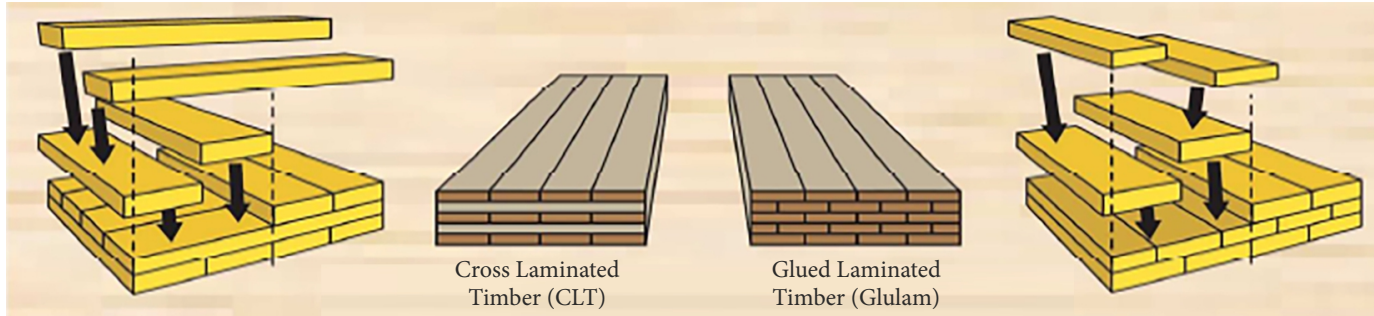

Figure 1. Difference between CLT and glulam (Avellan, 2018) 
2015). All timber products store carbon. By nature, wood is composed of carbon that is captured from the atmosphere during tree growth. Two effects - substitution and sequestration - create positive carbon impact of timber products (Bergman, Puettmann, Taylor, \& Skog, 2014). Study by Börjesson and Gustavsson (2000) reveals that the primary energy input (mainly fossil fuels) in the production of building materials is about $60-80 \%$ lower for timber frames compared to concrete frames.

Petersen and Solberg (2002) compared the use of glued laminated beams at the Gardermoen airport outside Oslo with an alternative solution to steel. They found that the total energy consumption in manufacturing of steel beams is $2-3$ times higher and the use of fossil fuel 6-12 times higher than in the manufacturing of glulam beams. Skullestad, Bohne, and Lohne (2016) have applied life cycle assessment to compare the climate change impact of a reinforced concrete structure to the climate change impact of an alternative timber structure for 4 buildings ranging from 3 to 21 storeys. According to attributional life cycle assessment results, the timber structures can cause a $34-84 \%$ lower climate change impact than the reinforced concrete structures.

The thermal resistance of wood is 500 times greater than that of steel and 10 times greater than concrete. In terms of energy efficiency, wood is a good heat insulator. Its use in construction reduces thermal bridges and increases the heat capacity of walls. Wood products also offer excellent acoustical performance. Their ratings are higher than those for concrete when it comes to the transmission of impact noise (QWEB, 2015).

From the economic perspective, timber products are a cost-effective solution since they are structurally efficient, light weight, easy and quick to install at the construction site (QWEB, 2015). Higher speed of assembly is also linked to reduced labour hours and project cost (Franzini, Toivonen, \& Toppinen, 2018).

Aforementioned environmental and economic benefits are further analysed in the multiple criteria comparison of modern high-rise timber buildings.

\section{Methodology}

Various multiple criteria decision-making methods can be applied for the assessment of alternatives with different purposes. One of the oldest and most widely used methods is the Simple Additive Weighting (SAW) method (MacCrimmon, 1968); therefore, it was selected by the authors for the purpose of the present research. Application methodology is depicted in Figure 2.

Initially, the analysis of contemporary high-rise timber buildings was performed and projects of highest buildings available worldwide were distinguished.

The purpose of this research was to compare contemporary high-rise timber buildings and to select the most efficient ones in terms of economic and environmental efficiency. To solve this task, the multiple criteria assessment of the buildings was performed by SAW method as follows.

Step 1. Development of the decision-making matrix

Decision-making matrix consists of alternatives and assessment criteria (attributes) and can be expressed as follows:

$$
P=\left[x_{i j}\right]_{[m \times n]}, i=\overline{1, m}, j=\overline{1, n},
$$

where $n$ is the number of assessed high-rise timber buildings; $m$ - the number of assessment criteria (attributes); $x_{i j}$ - the attribute value of the $j^{\text {th }}$ high-rise timber building. Step 2. Determination of the optimal values of each attribute

To determine the optimal value of each attribute, criteria with the highest (Max) and lowest (Min) preferred values have been determined. For instance, in case of cost, the lower value was preferred (Eq. (2a)) and in the case of building architectural height higher value was preferred (Eq. (2b)):

$$
\begin{aligned}
& x_{i}^{*}=\min _{i} x_{i j} ; \\
& x_{i}^{*}=\max _{i} x_{i j} .
\end{aligned}
$$

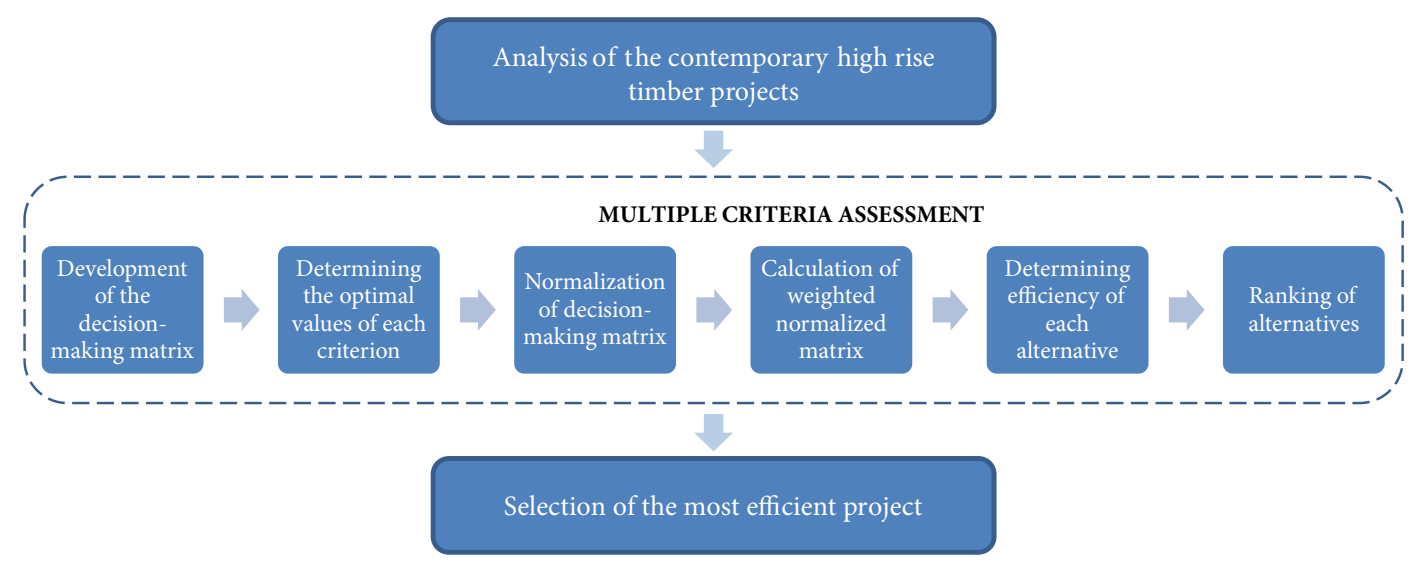

Figure 2. Research methodology 
Step 3. Normalization of decision-making matrix

Normalization of the decision-making matrix is performed to calculate the dimensionless values of the attributes. Following equations are used:

$$
\bar{x}_{i j}=\frac{\min _{i} x_{i j}}{x_{i j}},
$$

if preferable is minimum of the $i^{\text {th }}$ attribute;

$$
\bar{x}_{i j}=\frac{x_{i j}}{\max _{i} x_{i j}},
$$

if preferable is maximum of the $i^{\text {th }}$ attribute.

Step 4. Weighting of the normalized decision-making matrix

Weighting is performed by multiplying values of the normalized matrix by the respective significance of each criterion $\left(q_{i}\right)$ according to Eq. (4):

$$
\hat{P}=\left[q_{i} \bar{x}_{i j}\right]_{[m \times n]}, i=\overline{1, m}, j=\overline{1, n} .
$$

Step 5. Determination of efficiency of each alternative

Efficiency index for each $j^{\text {th }}$ high-rise timber building is determined by Eq. (5) as follows:

$$
K_{j}=\sum_{i=1}^{m} \hat{x}_{i j}, i=\overline{1, m}, j=\overline{1, n} .
$$

Step 6. Ranking of alternatives

Ranking of the compared high-rise timber buildings is based on efficiency indexes. The higher is the index, the higher is the rank. Ranks are specified in descending order. First ranked project is assumed to be the most efficient one.

\section{Assessment results}

\subsection{Description of the buildings}

Five high-rise timber buildings have been selected for comparison and multiple criteria assessment. All selected buildings are already completed and currently are among the highest modern timber constructed buildings in the world. Brief description of the buildings is provided below.

Mjøsa Tower $\left(A_{1}\right)$. Mjøsa Tower, at present, is the tallest timber building in the world, the tower is $85.4 \mathrm{~m}$-tall (18-storey) and is a multifunctional building located in Brumunddal, Norway, completed in March 2019. The tower encompasses hotel, offices and residential apartments (Figure 3).

The load-bearing structure is made of Kerto laminated veneer lumber (LVL), with glulam columns and beams. Prefabricated wooden elements make up the first ten floors while the upper floor decks are constructed of concrete, which adds more weight to stabilise the building. Prefabricated sections allowed completing construction significantly quicker compared to a concrete building of the same height. The environmental impact of the construction of Mjøsa Tower was designed to be kept at a minimum, with most of the materials sourced within two miles of the site (Design-Build Network, 2019).
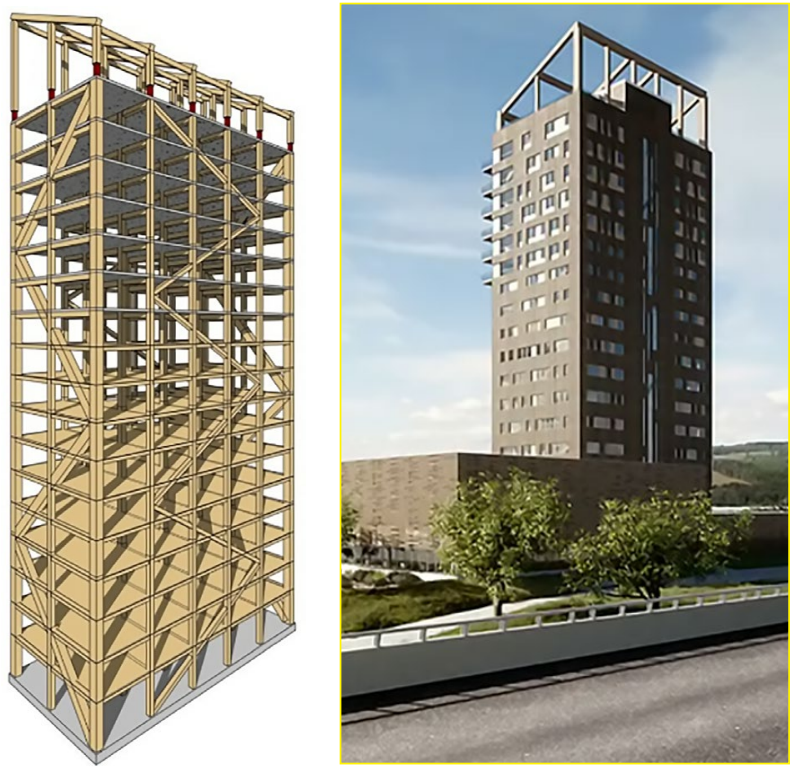

Figure 3. Mjøsa Tower, Brumunddal, Norway

(Voll Arkitekter, 2019)

Brock Commons Tallwood House $\left(A_{2}\right)$. Brock Commons is $53 \mathrm{~m}$-tall student accommodation facility at the University of British Columbia in Vancouver, Canada, capable to accommodate 404 students (Figure 4).

The $15,000 \mathrm{~m}^{2}$ project has a hybrid structure, with 17 storeys of CLT floors supported on glulam columns on top of a concrete base, and two 18-storey concrete cores. The roof comprises steel beams and metal decking. The building envelope is a prefabricated panel system clad with wood-fibre high-pressure laminate. Its designers claim that the structure is 7,500 tones lighter than a concrete equivalent (WSP, 2018). To comply with fire regulations, which were made stricter than for traditional steel or reinforced concrete buildings, interior wood materials were covered with gypsum board (Design Build Network, 2019). As the building was made of prefabricated components its construction was completed 70 days after the components were delivered on-site in 2017.

Treet/The Tree $\left(A_{3}\right)$. Treet or The Tree is a $49 \mathrm{~m}$-tall 14-storey apartment block in Bergen, Norway, completed in 2015 , four years after the design process commenced in 2011 (Figure 5). Treet has a glulam load-bearing structure supporting 62 prefabricated modular flats with walls made from CLT. Building stiffness is achieved solely through the glulam structure, though further stability is provided by concrete slabs which form the floors at levels 6 and 11 . Parts of the building's façade are clad in glass and metal to protect the wood from weathering (Design-Build Network, 2019).

Forte Development (A4). Forte Development is a 32.2 $\mathrm{m}$-tall 9-storey building in Melbourne, Australia, completed in 2012 (Figure 6). It became Australia's first high-rise timber building. The building was constructed from CLT panels acting as shear walls. The panels were stacked at right angles, glued over the surface and pressed hydraulically. The Forte Development features 23 residential apart- 


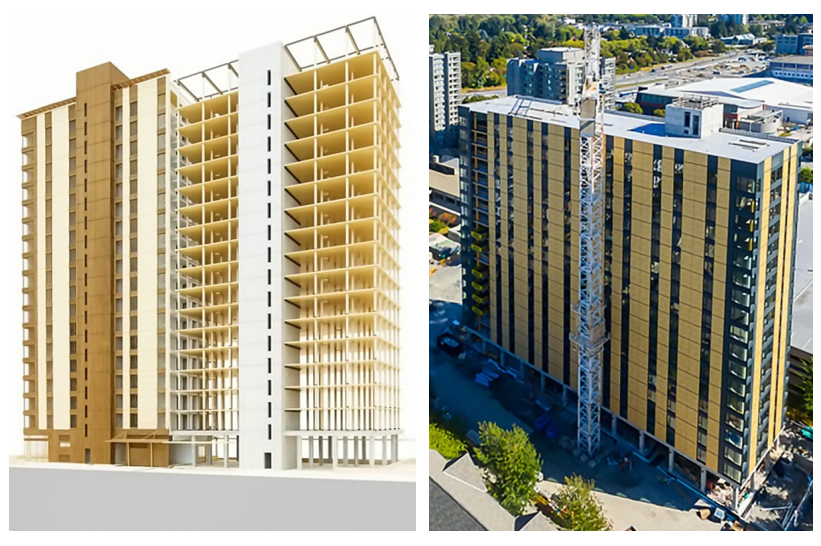

Figure 4. Brock Commons Tallwood House, Vancouver, Canada (Wood Skyscrapers, 2016; Archinect, 2016)
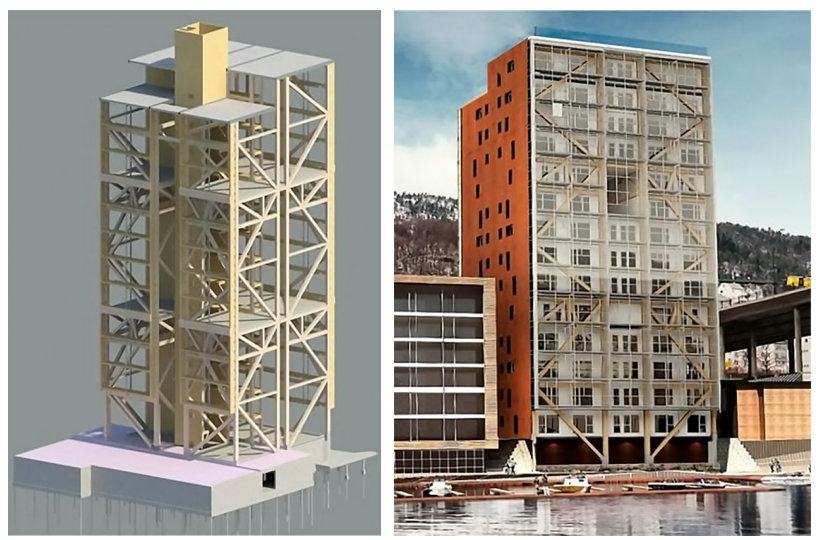

Figure 5. Treet, Bergen, Norway (Malo, Abrahamsen, \& Bjertnæs, 2016)
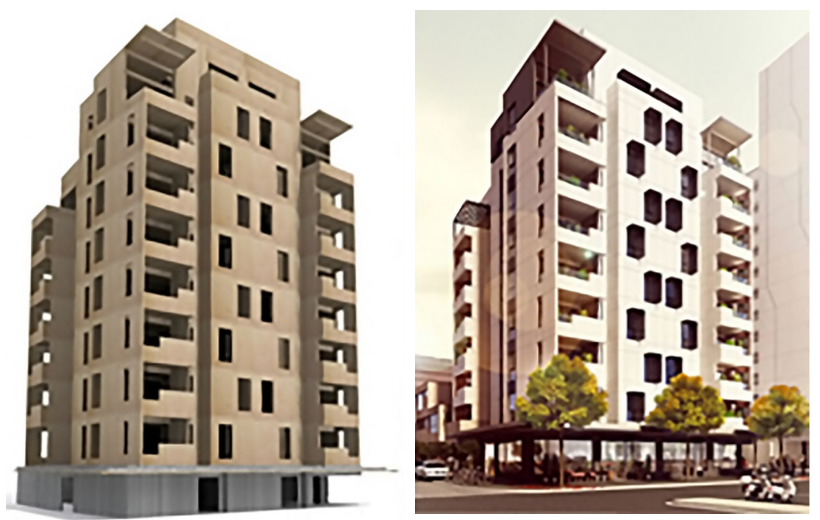

Figure 6. Forte Development, Melbourne, Australia (KLH UK, 2012)

ments and four townhouses. The apartments are dualaspect to make the most of natural lighting and have also been designed with thermal efficiency in mind, requiring less energy to be heated (Design Build Network, 2019).

Murray Grove Stadthaus $\left(A_{5}\right)$. The Murray Grove Stadthaus is a $26 \mathrm{~m}$-tall 9-storey residential building in Hackney, north-east London, UK, completed in 2009. It comprises 29 apartments (Figure 7).

Murray Grove was named the world's first housing high-rise building constructed entirely from prefabricated CLT panels, with its core, load-bearing walls, floor slabs,
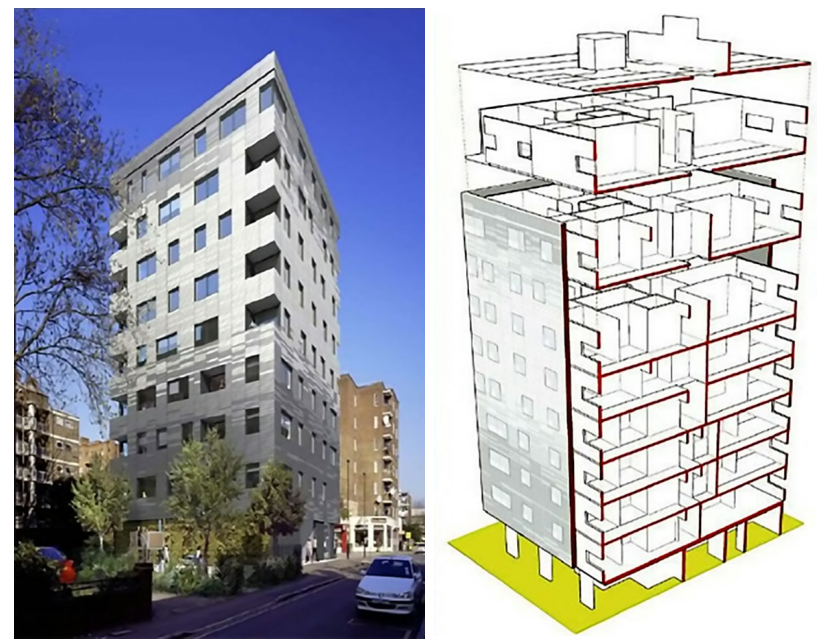

Figure 7. Murray Grove Stadthaus, London, UK (Cvetkovic, Stojić, Krasic, \& Marković, 2015)

stairs and lift cores. KLH CLT panels were used on the building's structural core due to their significantly higher density than timber frames. Independent layers were then added to maintain a high acoustic performance (Design Build Network, 2019).

\subsection{Assessment criteria}

To compare the selected high-rise timber buildings, seven criteria were established which reflect the intensity of timber used in construction. The assessment includes the achieved height in terms of meters and number of floors, duration of construction and cost efficiency as well as environmental parameters such as reduction of $\mathrm{CO}_{2}$ emission and energy use. Significances of criteria were determined by the authors of the present paper, based on their experience and the purpose of research (see Table 1).

\subsection{Multiple criteria assessment}

To perform multiple criteria assessment of the selected high-rise timber buildings, the SAW method was used (see Section 2). At the initial stage, the decision-making matrix was developed (see Table 2).

Next, normalization of the matrix was performed according to Eqs (3a) and 3(b) as described in Section 2 (Table 3).

Having normalized decision-making matrix, the weighted matrix was calculated according to Eq. (4), efficiency indexes were determined according to Eq. (5) and the final ranking of the high-rise timber buildings was performed (Table 4).

Calculations allowed ranking of the alternative highrise timber buildings as follows: $A_{1} \succ A_{2} \succ A_{4} \succ A_{3} \succ$ $A_{5}$. The Mjøsa Tower $\left(A_{1}\right)$, at present, the tallest timber building in the world has received the highest rank in terms of the evaluated criteria. It is followed by the Brock Commons Tallwood House $\left(A_{2}\right)$ and Forte Development in Melbourne $\left(A_{4}\right)$ respectively. The lowest ranks are the earlier implemented projects; Treet/The Tree $\left(A_{3}\right)$ and Murray Grove Stadthaus $\left(A_{5}\right)$. 
Table 1. Assessment criteria and their significances

\begin{tabular}{|c|c|c|c|c|c|}
\hline & Criterion & $\operatorname{Max} / \operatorname{Min}^{*}$ & $\begin{array}{l}\text { Measuring } \\
\text { unit }\end{array}$ & Description & Significance \\
\hline$q_{1}$ & $\begin{array}{l}\text { Use of } \\
\text { wood }\end{array}$ & Max & $\mathrm{m}^{3} / \mathrm{m}^{2}$ & $\begin{array}{l}\text { Relative indicator expressing the proportion of used wooden structures } \\
\left(\mathrm{m}^{3}\right) \text { per square meter of building. Higher use of wood is preferred. }\end{array}$ & 0.2 \\
\hline$q_{2}$ & $\begin{array}{l}\text { Height of } \\
\text { the building }\end{array}$ & Max & $\mathrm{m}$ & $\begin{array}{l}\text { Architectural height of the building. The aim is to achieve tallest } \\
\text { buildings in timber, therefore higher number is preferred. }\end{array}$ & 0.2 \\
\hline$q_{3}$ & $\begin{array}{l}\text { Number of } \\
\text { floors }\end{array}$ & Max & number & $\begin{array}{l}\text { Number of ground floors in a building, sometimes buildings of the same } \\
\text { height may have different floors and vice versa. The higher the number } \\
\text { of floors, the larger the area of the building can be used. }\end{array}$ & 0.1 \\
\hline$q_{4}$ & $\begin{array}{l}\text { Building } \\
\text { cost }\end{array}$ & Min & Eur $/ \mathrm{m}^{2}$ & $\begin{array}{l}\text { Ratio of the cost of the project to the total area. The lower the cost, the } \\
\text { more cost-effective the project is. }\end{array}$ & 0.1 \\
\hline$q_{5}$ & $\begin{array}{l}\text { Length of } \\
\text { implemen- } \\
\text { tation }\end{array}$ & Min & $\begin{array}{l}\text { number of } \\
\text { days per } \\
\text { floor }\end{array}$ & $\begin{array}{l}\text { Time in working days needed to install load-bearing structures of } \\
\text { one floor. The shorter the installation time, the more economical the } \\
\text { construction of the building. }\end{array}$ & 0.1 \\
\hline$q_{6}$ & $\begin{array}{l}\text { Reduction } \\
\text { of } \mathrm{CO}_{2} \\
\text { emission }\end{array}$ & Max & tones & $\begin{array}{l}\text { Reduced amount of } \mathrm{CO}_{2} \text { emission compared to a reinforced concrete } \\
\text { building. The higher the difference, the lower the environmental impact } \\
\text { of the timber building. }\end{array}$ & 0.2 \\
\hline$q_{7}$ & $\begin{array}{l}\text { Use of } \\
\text { energy }\end{array}$ & Min & $\begin{array}{l}\mathrm{kW} / \mathrm{m}^{2} \\
\text { per year }\end{array}$ & $\begin{array}{l}\text { Annual energy consumption per square meter of a building. The lower } \\
\text { the quantity, the more energy efficient is the building and the less } \\
\text { negative impact it has on the natural environment. }\end{array}$ & 0.1 \\
\hline
\end{tabular}

Note: ${ }^{\star} \mathrm{Max}$ - higher value of criterion is preferred; Min - lower value of criterion is preferred.

Table 2. Decision-making matrix

\begin{tabular}{|l|c|c|c|c|c|c|c|}
\hline & \multirow{2}{*}{ Max/Min } & \multirow{2}{*}{$\begin{array}{c}\text { Significance } \\
\text { of criterion }\end{array}$} & \multicolumn{4}{|c|}{ Alternatives } \\
\cline { 5 - 9 } & & & $A_{1}$ & $A_{2}$ & $A_{3}$ & $A_{4}$ & $A_{5}$ \\
\hline Use of wood & Max & 0.2 & 0.25 & 0.15 & 0.16 & 0.46 & 0.31 \\
\hline Height of the building & Max & 0.2 & 85.4 & 54 & 52.8 & 32.2 & 26 \\
\hline Number of floors & Max & 0.1 & 18 & 18 & 14 & 9 & 9 \\
\hline Building cost & Min & 0.1 & 4872 & 2045 & 3774 & 5157 & 1546 \\
\hline Length of implementation & Min & 0.1 & 12 & 12 & 15 & 6 & 7 \\
\hline Reduction of $\mathrm{CO}_{2}$ emission & Max & 0.2 & 1577 & 2432 & 2000 & 1451 & 310 \\
\hline Use of energy & Min & 0.1 & 102 & 135 & 84 & 120 & 144 \\
\hline
\end{tabular}

Table 3. Decision-making matrix after normalization

\begin{tabular}{|l|c|c|c|c|c|c|c|}
\hline & \multirow{2}{*}{ Max/Min } & \multirow{2}{*}{$\begin{array}{c}\text { Significance } \\
\text { of criterion }\end{array}$} & \multicolumn{4}{|c|}{ Alternatives } \\
\cline { 6 - 9 } & & & $A_{1}$ & $A_{2}$ & $A_{3}$ & $A_{4}$ & $A_{5}$ \\
\hline Use of wood & Max & 0.2 & 0.806 & 0.326 & 0.348 & 1.000 & 0.674 \\
\hline Height of the building & Max & 0.2 & 1.000 & 0.632 & 0.618 & 0.377 & 0.304 \\
\hline Number of floors & Max & 0.1 & 1.000 & 1.000 & 0.778 & 0.500 & 0.500 \\
\hline Building cost & Min & 0.1 & 0.317 & 0.756 & 0.410 & 0.300 & 1.000 \\
\hline Length of implementation & Min & 0.1 & 0.500 & 0.500 & 0.400 & 1.000 & 0.857 \\
\hline Reduction of $\mathrm{CO}_{2}$ emission & Max & 0.2 & 0.648 & 1.000 & 0.822 & 0.597 & 0.127 \\
\hline Use of energy & Min & 0.1 & 0.824 & 0.622 & 1.000 & 0.700 & 0.583 \\
\hline
\end{tabular}

\section{Conclusions}

Technology advancements and engineered timber products such as glulam, CLT, and LVL allow building highrise timber buildings. Currently, the tallest timber building in the world is $85.4 \mathrm{~m}$-tall 18-storey (Mjøsa Tower). Its load-bearing structure is made from Kerto LVL with glulam columns and beams.
Contemporary timber structures have benefits compared to steel and concrete structures. Wood is environmentally friendly and is the only available renewable construction material. The primary energy input (mainly fossil fuels) in the production of timber building materials is lower compared to concrete and other materials; moreover, wood is a good heat insulator. Construction from timber is cost-efficient due to prefabrication of ele- 
Table 4. Weighted decision-making matrix and ranking of alternatives

\begin{tabular}{|l|c|c|c|c|c|}
\hline \multirow{2}{*}{} & \multicolumn{3}{|c|}{ Alternatives } & $A_{4}$ & $A_{5}$ \\
\cline { 2 - 6 } & $A_{1}$ & $A_{2}$ & $A_{3}$ & 0.200 & 0.135 \\
\hline Use of wood & 0.161 & 0.065 & 0.070 & 0.075 & 0.061 \\
\hline Height of the building & 0.200 & 0.126 & 0.124 & 0.050 & 0.050 \\
\hline Number of floors & 0.100 & 0.100 & 0.078 & 0.030 & 0.100 \\
\hline Building cost & 0.032 & 0.076 & 0.041 & 0.100 & 0.086 \\
\hline Length of implementation & 0.050 & 0.050 & 0.040 & 0.119 & 0.025 \\
\hline Reduction of $\mathrm{CO}_{2}$ emission & 0.130 & 0.200 & 0.164 & 0.070 & 0.058 \\
\hline Use of energy & 0.082 & 0.062 & 0.100 & 0.645 & 0.515 \\
\hline Efficiency $\left(K_{j}\right)$ & 0.755 & 0.680 & 0.616 & 3 & 5 \\
\hline Rank & 1 & 2 & 4 & & 5 \\
\hline
\end{tabular}

ments, lower transportation costs, and reduced duration of the project.

Multiple criteria assessment allows coming to the conclusion that higher timber buildings are efficient from both economic and environmental perspectives as the highest buildings received higher ranking positions.

In the present research, however, some limitations exist. First, the system of assessment criteria is limited to most commonly used ones even though it will be extended in future research. Second, significances of the criteria were determined by authors of the present paper. In the future research, expert evaluation will also be used. Third, the assessment of buildings was based on the SAW method. In future research, the authors will use other multiplecriteria methods to verify the obtained results.

\section{Funding}

This work was supported by the EU ERASMUS + projects "Sustainable High-Rise Buildings Designed and Constructed in Timber" (HiTimber) (Project No: 2017-1-DK01-KA203-034242), "Sustainable Public Buildings Designed and Constructed in Wood" (Pub-Wood) (Project No: 2018-1-LT01-KA203-046963), and "Knowledge Alliance for Sustainable Mid-Rise and Tall Wooden Buildings" (KnoWood) (Project No: 600903-EPP-1-2018-1-DKEPPKA2-KA).

\section{Author contributions}

All authors contributed to preparation of publication.

\section{Disclosure statement}

Authors do not have any competing financial, professional, or personal interests from other parties.

\section{References}

Archinect. (2016). World's tallest wood building constructed in Vancouver. Retrieved from https://archinect.com/news/gallery/149968916/1/world-s-tallest-wood-building-constructed-in-vancouver
Avellan, K. C. (2018, April 25-27). Massive wood elements and modular housing technology as innovative building concept of sustainable urban planning. Paper preseted at IABSE Conference - Engineering the Developing World, Kuala Lumpur, Malaysia.

Bergman, R., Puettmann, M., Taylor, A., \& Skog, K. E. (2014). The carbon impacts of wood products. Forest Products Journal, 64(7/8), 220-231. https://doi.org/10.13073/FPJ-D-14-00047

Börjesson, P., \& Gustavsson, L. (2000). Greenhouse gas balances in building construction: wood versus concrete from life-cycle and forest land-use perspectives. Energy Policy, 28, 575588. https://doi.org/10.1016/S0301-4215(00)00049-5

Craighead, G. (2003). High-rise security and fire safety (2nd ed.). Woburn, MA: Butterworth-Heinemann.

Cvetkovic, R., Stojić, D., Krasic, S., \& Marković, N. (2015). Innovative structural CLT system in projecting and building of student houses. Facta universitatis - Series Architecture and Civil Engineering, 13(1), 57-64.

https://doi.org/10.2298/FUACE1501057C

Design Build Network. (2019). The world's tallest wooden buildings. Retrieved from https://www.designbuild-network.com/ features/worlds-tallest-wooden-buildings/

Franzini, F., Toivonen, R., \& Toppinen, A. (2018). Why not wood? Benefits and barriers of wood as a multistory construction material: Perceptions of municipal civil servants from Finland. Buildings, 8, 159.

https://doi.org/10.3390/buildings8110159

Gilbert, B. P., Bailleres, H., Zhang, H., \& McGavin, R. L. (2017). Strength modelling of Laminated Veneer Lumber (LVL) beams. Construction and Building Materials, 149, 763-777. https://doi.org/10.1016/j.conbuildmat.2017.05.153

KLH UK. (2012). Lendlease launches world's tallest KLH tower. Retrieved from http://www.klhuk.com/news/c2east.aspx

MacCrimmon, K. R. (1968). Decision making among multiple attribute alternatives: A survey and consolidated approach. RAND Memorandum, RM-4823-ARPA.

Mahapatra, K., Gustavsson, L., \& Hemström, K. (2012). Multistorey wood-frame buildings in Germany, Sweden and the UK. Construction Innovation, 12(1), 62-85. https://doi.org/10.1108/14714171211197508

Malo, K. A., Abrahamsen, R. B., \& Bjertnæs, M. A. (2016). Some structural design issues of the 14-storey timber framed building "Treet" in Norway. European Journal of Wood and Wood Products, 74(3), 407-424.

https://doi.org/10.1007/s00107-016-1022-5

Petersen, A. K., \& Solberg, B. (2002). Greenhouse gas emissions, life-cycle inventory and cost-efficiency of using laminated 
wood instead of steel construction. Case: beams at Gardermoen airport. Environmental Science \& Policy, 5, 169-182. https://doi.org/10.1016/S1462-9011(01)00044-2

Quebec Wood Export Bureau (QWEB). (2015). Wood construction technologies in Quebec, Canada. Retrieved from http:// www.quebecwoodexport.com/images/stories/pdf/Catalogue AN_13-04-2016.pdf

Ramage, M. H., Burridge, H., Busse-Wicher, M., Fereday, G., Reynolds, T., Shah, D. U., Wu, G., Yu, L., Fleming, P., Densley-Tingley, D., Allwood, J., Dupree, P., Linden, P. F., \& Scherman, O. (2017). The wood from the trees: The use of timber in construction. Renewable and Sustainable Energy Reviews, 68, 333-359. https://doi.org/10.1016/j.rser.2016.09.107

Skullestad, J. L., Bohne, R. A., \& Lohne, J. (2016). High-rise timber buildings as a climate change mitigation measure A comparative LCA of structural system alternatives. Energy Procedia, 96, 112-123.

https://doi.org/10.1016/j.egypro.2016.09.112

Van De Kuilen, J. W. G., Ceccotti, A., Xia, Z., \& He, M. (2011). Very tall wooden buildings with cross laminated timber. Procedia Engineering, 14, 1621-1628.

https://doi.org/10.1016/j.proeng.2011.07.204

Voll Arkitekter. (2019). Mjøsa Tower. Retrieved from http://vollark.no/portfolio_page/mjostarnet/

Wood Skyscrapers. (2016). World's tallest mass timber building-UBC Brock Commons 18 Stories residence rises. Retrieved from http:// www.woodskyscrapers.org/blog/worlds-tallest-mass-timberbuilding-ubc-brock-commons-18-storie-residence-rises

WSP. (2018). Tall timber: How high can CLT go? Retrieved from https://www.wsp.com/en-RO/insights/tall-timber-how-highcan-clt-go 